\title{
ELECTRODEPOSITION OF Nb AND AI FROM CHLOROALUMINATE MELT ON VITREOUS CARBON
}

\author{
Nataša M. Vukićevićl, Vesna S. Cvetkovic ${ }^{1 *}$, Ljiljana S. Jovanović ${ }^{2}$, \\ Olga S. Radulović ${ }^{1}$, Jovan N. Jovićevic ${ }^{1}$ \\ ${ }^{1}$ ICTM, Department of Electrochemistry, University of Belgrade, Njegoševa 12, \\ 11000 Belgrade, Serbia, \\ ${ }^{2}$ Faculty of Sciences, University of Novi Sad, Trg D. Obradovića 3, 21000 N. \\ Sad, Serbia.
}

Received 16.03.2016

Accepted 25.03.2016

\begin{abstract}
Niobium and aluminium were electrodeposited at $200{ }^{\circ} \mathrm{C}$ under argon atmosphere onto vitreous carbon from inorganic chloroaluminate melts $\left(\mathrm{AlCl}_{3}+\mathrm{NaCl}\right)$ with added niobium. Niobium was introduced into the electrolyte by anodic dissolution of metallic niobium or by chemical dissolution of $\mathrm{Nb}_{2} \mathrm{O}_{5}$ in a melt of equimolar $\mathrm{AlCl}_{3}+\mathrm{NaCl}$ mixture. The processes of deposition/dissolution onto/from vitreous carbon were investigated by cyclic voltammetry and chronoamperometry. Characterization of the obtained deposits was done by Scanning Electron Microscopy (SEM) and Energy Dispersive Spectroscopy (EDS). The only observed reduction processes on the working electrode in the potential window from $1.000 \mathrm{~V}$ to $-1.000 \mathrm{~V}$ vs. Al, were individual niobium deposition and codeposition of niobium and aluminium with $\mathrm{Al}-\mathrm{Nb}$ alloys formation.

Electrodeposition of niobium from the chloroaluminate melt with added niobium (V) oxide seems to start at around $-0.100 \mathrm{~V}$ vs. $\mathrm{Al}$ and at about $-0.200 \mathrm{~V}$ vs. $\mathrm{Al}$ aluminium starts codepositing. During the codeposition $\mathrm{Nb}-\mathrm{Al}$ alloys were formed. Niobium deposition starting potential from the electrolyte with niobium added by anodic dissolution starts at $0.100 \mathrm{~V}$ vs. $\mathrm{Al}$, and aluminium codeposition starting potential was at around $-0.025 \mathrm{~V}$ vs. Al, followed by $\mathrm{Nb} / \mathrm{Al}$ alloy formation.

Keywords: Electrochemical deposition, chloroaluminate melts, niobium, aluminium, Al$\mathrm{Nb}$ alloys
\end{abstract}

\footnotetext{
*Corresponding author: Vesna Cvetković, E-mail: v.cvetkovic@ihtm.bg.ac.rs
} 


\section{Introduction}

Last 50 years have seen increasing demand for niobium and its alloys [1]. Niobium's specific characteristics like corrosion resistivity, superconductivity, thermostability and biocompatibility, make it very interesting basic or added component for alloys. Niobium alloys are successfully applied in electronic, automotive, nuclear and space industry, but also in medical aids and implants productions [1-3].

Metallurgical processes for production of niobium [4] and its alloys [5,6] are complicated (high or low pressures, high or low temperatures) and expensive [7]. Therefore, research and development efforts into niobium electrodeposition as a viable manufacturing alternative have intensified [8-11]. The melts made of chloride and fluoride salts were found to be suitable electrolytes for electrodeposition of niobium and some of its alloys [8-16]. However, these melts require operating temperatures well above $500{ }^{\circ} \mathrm{C}$ and produce toxic and corrosive fumes.

Relatively recently efforts have resulted in development of non-aqueous electrolytes-melts which can be stable at temperatures below $100{ }^{\circ} \mathrm{C}$, so called ionic liquids $[17,18]$. Although ionic liquids seem to be suitable media for the application, the electrodeposition processes of niobium and its alloys from these electrolytes have not yet been extensively investigated.

In the relevant literature, there is evidence of attempts to electrodeposit niobium on graphite, vitreous carbon, diamond, steel, $\mathrm{Ni}, \mathrm{Mo}, \mathrm{Mg}, \mathrm{W}, \mathrm{Nb}, \mathrm{Pt}, \mathrm{Fe}, \mathrm{Cu}$, etc., from melts made of different combinations of $\mathrm{Na}, \mathrm{K}, \mathrm{Li}, \mathrm{Cs}, \mathrm{Ca}, \mathrm{Al}$ chlorides and fluorides. Some of those works [12,19-24] describe alloys being formed from cathode substrate and $\mathrm{Nb}$ deposited. However, there are only a few works [11,22,23,25,26] describing $\mathrm{Al}$ and $\mathrm{Nb}$ co-deposition that results in $\mathrm{Nb}-\mathrm{Al}$ alloy formation and those are on $\mathrm{W}, \mathrm{Cu}$ and $\mathrm{Nb}$ cathodes, but not on vitreous carbon.

The aim of this work was to investigate the possibility of niobium deposition and aluminium-niobium codeposition on vitreous carbon from a low temperature melt made of equimolar $\mathrm{AlCl}_{3}+\mathrm{NaCl}$ mixture with added niobium ions.

\section{Experimental}

All electrochemical experiments were performed in a three neck Pyrex glass cell, described elsewhere [27], under inert argon atmosphere at $200{ }^{\circ} \mathrm{C}$. Central Teflon plug carried a vitreous carbon - working electrode with $0.5 \mathrm{~cm}^{2}$ active surface; left plug held a shovel shaped anode of niobium $\left(5 \mathrm{~cm}^{2} 99.95 \% \mathrm{Nb}\right)$ and argon inlet/outlet; right plug held a Luggin capillary with an aluminium reference electrode (cylindrical rod $3 \mathrm{~mm}$ in diameter, $99.999 \% \mathrm{Al}$ ) and a thermocouple connected to a thermostat of the thermo mantel. Experiments were performed in a hermetically sealed acrylic glove box. Electrochemical techniques were applied and results recorded by an EG\&G PAR Potentiostat/Galvanostat Model 273A supplied with Power Suite software (Princeton Applied Research).

Working surface of the vitreous carbon electrode was mechanically polished on emery paper, and then on polishing cloth impregnated with $\mathrm{Al}_{2} \mathrm{O}_{3}$ powder. Finally, the electrode was washed in diluted $\mathrm{HCl}$ and rinsed in distilled and then deionised water. Aluminium electrodes surfaces were mechanically polished by emery paper and chemically etched in water solution of $50 \% \mathrm{HF}+15 \% \mathrm{H}_{2} \mathrm{O}_{2}$ with intense stirring for 30 to $60 \mathrm{~s}$, followed by 30 to $60 \mathrm{~s}$ of rest in the solution of cc. $\mathrm{NH}_{4} \mathrm{NO}_{3}+5 \% \mathrm{H}_{2} \mathrm{O}_{2}$. Finally the electrodes were rinsed with distilled water, deionised water and absolute ethanol. 
Niobium electrodes were mechanically polished by emery paper and etched in acid mixture of cc. $\mathrm{HF}$ : cc. $\mathrm{HNO}_{3}=3: 1$ in three intervals each of $10 \mathrm{~s}$ interrupted by rinsing in deionised water and finally washed with absolute ethanol.

The electrolyte used was a melt of equimolar $\mathrm{AlCl}_{3}+\mathrm{NaCl}$ mixture enriched with $\mathrm{Nb}$ ions by chemically dissolved $\mathrm{Nb}_{2} \mathrm{O}_{5}$ or anodically dissolved $\mathrm{Nb}$ metal. Only fresh anhydrous $\mathrm{AlCl}_{3}$ was used for each melt preparation. It was placed at the bottom of the cell and covered with $\mathrm{NaCl}$ which was previously dried for 10 hours at $550{ }^{\circ} \mathrm{C}$. Mixture was then heated slowly to $200{ }^{\circ} \mathrm{C}$ until colourless liquid electrolyte was apparent. The liquid electrolyte was then subjected to pre-electrolysis (working electrode $99.999 \mathrm{Pt}$; counter and reference electrodes $99.999 \% \mathrm{Al}$ ) under argon atmosphere and current density of $-0.2 \mathrm{mAcm}^{-2}$.

In the case of niobium being added by anodic dissolution of $\mathrm{Nb}$ metal, all the cell electrodes were niobium and working electrode was dissolved under argon atmosphere (the current density applied was $150 \mathrm{mAcm}^{-2}$ ) long enough to secure the wanted $\mathrm{Nb}$ concentration $[23,25]$. Typically dissolved $\mathrm{Nb}$ corresponded to about 0.4 to $1.2 \mathrm{~mol} \%$ of $\mathrm{NbCl}_{5}$ in the melt, which was recorded by weighting niobium anode.

Cyclic voltammetry experiments were performed by changing working electrode potential (measured versus Al reference electrode) at a chosen sweep rate (from $5 \mathrm{mVs}^{-1}$ to $500 \mathrm{mVs}^{-1}$ ) from initial potential, $\mathrm{E}_{\mathrm{i}}$ (usually $50 \mathrm{mV}$ negative to equilibrium potential of vitreous carbon) to cathodic end potential, $E_{f}$, and back to $E_{i}$. Some of the cyclic voltammograms were obtained after the cathodic end potential, $\mathrm{E}_{\mathrm{f}}$, was held constant for some time before the reverse part of the cycle was performed. Potentiostatic experiments were carried out within the same potential windows by holding cathodic end potentials for 2-4 hours whereupon cathodes were withdrawn from the cell under applied potential. The surfaces of these electrodes were analyzed by scanning electron microscopy (SEM „JEOL”, model JSM-5800, Japan) and energy dispersive spectroscopy (EDS, „Oxford INCA 3.2“, U.K.).

\section{Results and discussion}

Cyclic voltammogram recorded with vitreous carbon electrode in the melt made of equimolar $\mathrm{AlCl}_{3}+\mathrm{NaCl}$ mixture at $200{ }^{\circ} \mathrm{C}$ within chosen potential window is shown in Fig. 1 and suggests start of aluminium deposition at around $-0.025 \mathrm{~V}$ vs. Al. It displays only deposition and dissolution of aluminium. 


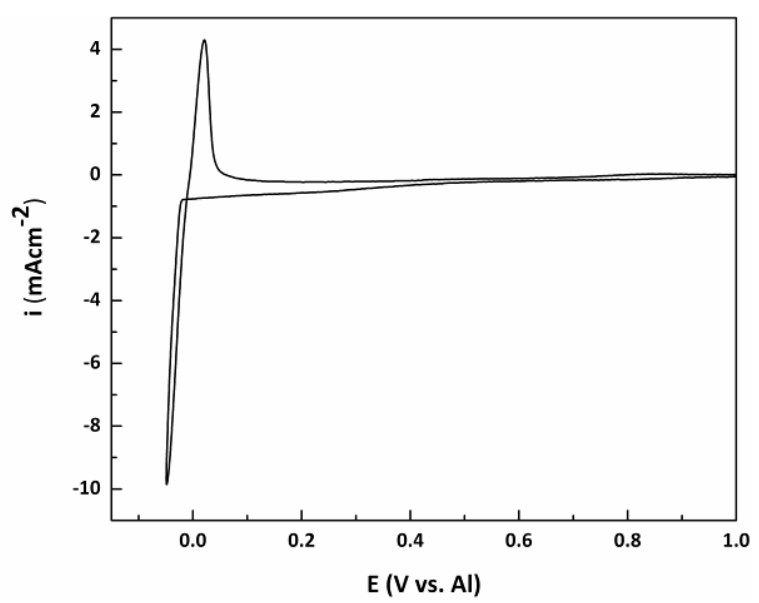

Fig.1. Voltammogram recorded with vitreous carbon electrode in $\mathrm{AlCl}_{3}+\mathrm{NaCl}$ melt, $v=$ $20 \mathrm{mV} / \mathrm{s} ; E_{i}=1.000 \mathrm{~V} \leftrightarrow E_{f}=-0.050 \mathrm{Vvs} . \mathrm{Al} ; \mathrm{T}=200{ }^{\circ} \mathrm{C}$.

Voltammograms obtained with vitreous carbon from the melt with niobium added by chemical dissolution of $\mathrm{Nb}_{2} \mathrm{O}_{5}$ are shown in Fig.2. a) and b). Those presented in Fig.2. a) show: one reduction and one oxidation peak ( $I$ and $I_{a}$ ) in the potential window from $1.000 \mathrm{~V}$ vs. Al to $0.100 \mathrm{~V}$ vs. Al; two reduction and two oxidation peaks (I, II and $\mathrm{I}_{\mathrm{a}}, \mathrm{II}_{\mathrm{a}}$ ) in the potential window from $1.000 \mathrm{~V}$ vs. Al to $-0.250 \mathrm{~V}$ vs. Al; two reduction peaks (I, II) and one reduction current increase (III); and two oxidation peaks $\left(\mathrm{I}_{\mathrm{a}}, \mathrm{II}_{\mathrm{a}}+\mathrm{III}_{\mathrm{a}}\right)$ in the potential window from $1.000 \mathrm{~V}$ vs. Al to $-0.500 \mathrm{~V}$ vs. Al. Fig.2. b) shows voltammograms recorded in the potential window from $1.000 \mathrm{~V}$ vs. Al to -1.000 $\mathrm{V}$ vs. Al scanned at different scan rates. Comparison of voltammograms of Fig.2 with the voltammogram from Fig.1 allows for assumptions that the first two reduction peaks (I and II) and their anodic counterparts (Ia and IIa) reflect niobium reduction and oxidation in two steps $[12,13,21]$. First step of $\mathrm{Nb}(\mathrm{V})$ into $\mathrm{Nb}(\mathrm{IV})$ appears at around $0.375 \mathrm{~V}$ vs. $\mathrm{Al}$, and second $\mathrm{Nb}(\mathrm{IV})$ into $\mathrm{Nb}$ at around $-0.100 \mathrm{~V}$ vs $\mathrm{Al}$. The $\mathrm{i}_{\text {peak }}=v^{1 / 2}$ analysis ( $\mathrm{i}_{\text {peak }}$ - maximum peak current, $v$ - sweep rate) for the second peaks (II and $\mathrm{II}_{\mathrm{a}}$ ) of the voltammograms presented in Fig. 2.b) revealed a linear function, which suggests diffusion controlled rate of the second step, i.e. $\mathrm{Nb}(\mathrm{IV})$ into $\mathrm{Nb}$ [28]. This would mean that niobium deposition, in the electrolyte used, proceeds under diffusion control at potentials more cathodic than $-0.100 \mathrm{~V}$ vs. Al, all the way to $-0.200 \mathrm{~V}$ vs. Al where aluminium deposition is observed as well. This was expected, because niobium concentration in the electrolyte was relatively small. It appears that aluminium and niobium codeposit at potentials more negative than $-0.250 \mathrm{~V}$ vs. Al. In fact, with increasing cathodic overpotential from $-0.200 \mathrm{~V}$ vs. Al onwards, $\mathrm{Nb}$ continues to deposit with diffusion limited current and aluminium with ever increasing rate. Anodic peaks (IIa and $\mathrm{II}_{\mathrm{a}}+\mathrm{III}_{\mathrm{a}}$ ) support the above assumptions. Two anodic peaks situated at most negative potentials in Fig 2. b) reflect: smaller one $\left(\mathrm{III}_{\mathrm{b}}\right)$ - a dissolution of deposited $\mathrm{Al}$ which did not enter $\mathrm{Nb}-\mathrm{Al}$ alloy; larger one $\left(\mathrm{II}_{\mathrm{a}}+\mathrm{III}_{\mathrm{a}}\right)$ - a dissolution of codeposited $\mathrm{Al}$ and $\mathrm{Nb}$, most probably $\mathrm{Nb}-\mathrm{Al}$ alloy with different $\mathrm{Nb}$ participation. 

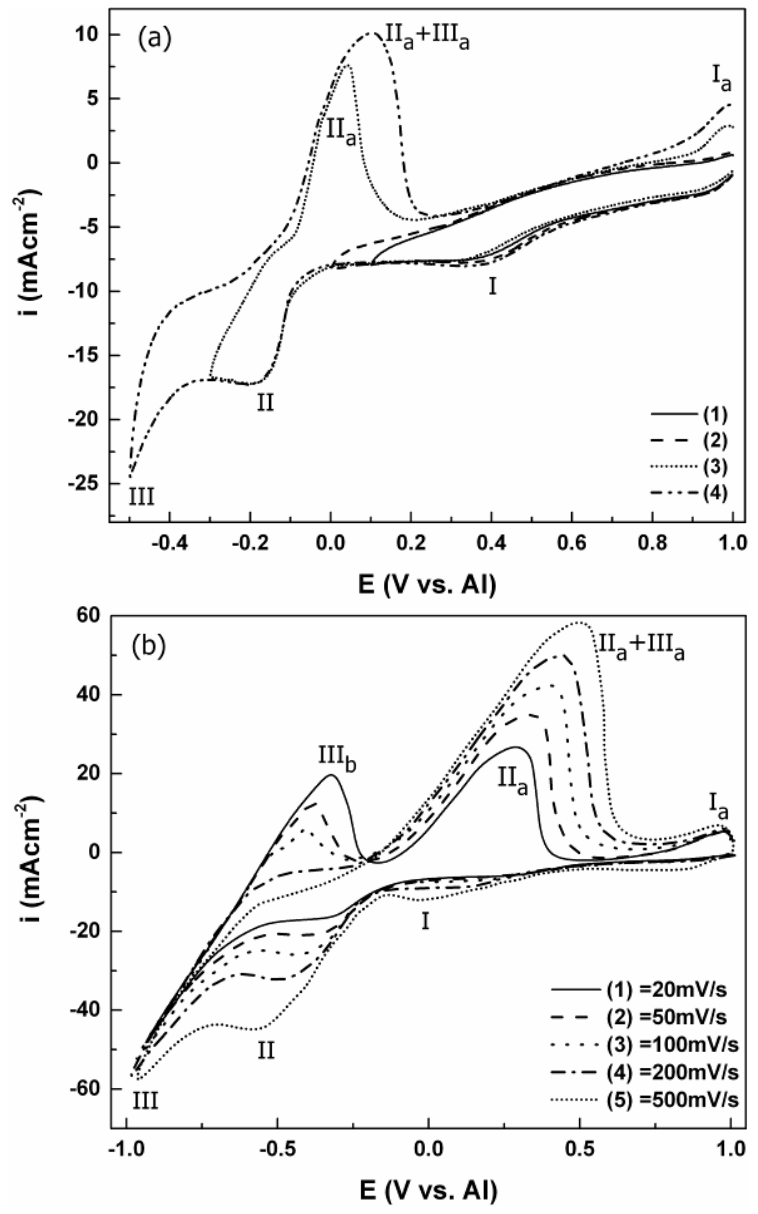

Fig. 2. Voltammograms recorded with vitreous carbon electrode in $\mathrm{AlCl}_{3}+\mathrm{NaCl}$ melt with $\mathrm{Nb}_{2} \mathrm{O}_{5}$ added, $\mathrm{T}=200{ }^{\circ} \mathrm{C}$; a) $E_{i}=1.000 \mathrm{~V} \leftrightarrow E_{f(1)}=0.100 \mathrm{~V} ; E_{f(2)}=0.000 \mathrm{~V}$;

$E_{f(3)}=-0.300 \mathrm{~V} ; E_{f(4)}=-0.500 \mathrm{Vvs} . \mathrm{Al} ; \mathrm{v}=20 \mathrm{mV} / \mathrm{s}$,

b) $E_{i}=1.000 \mathrm{~V} \leftrightarrow E_{f}=-1.000 \mathrm{Vvs.Al}$ 

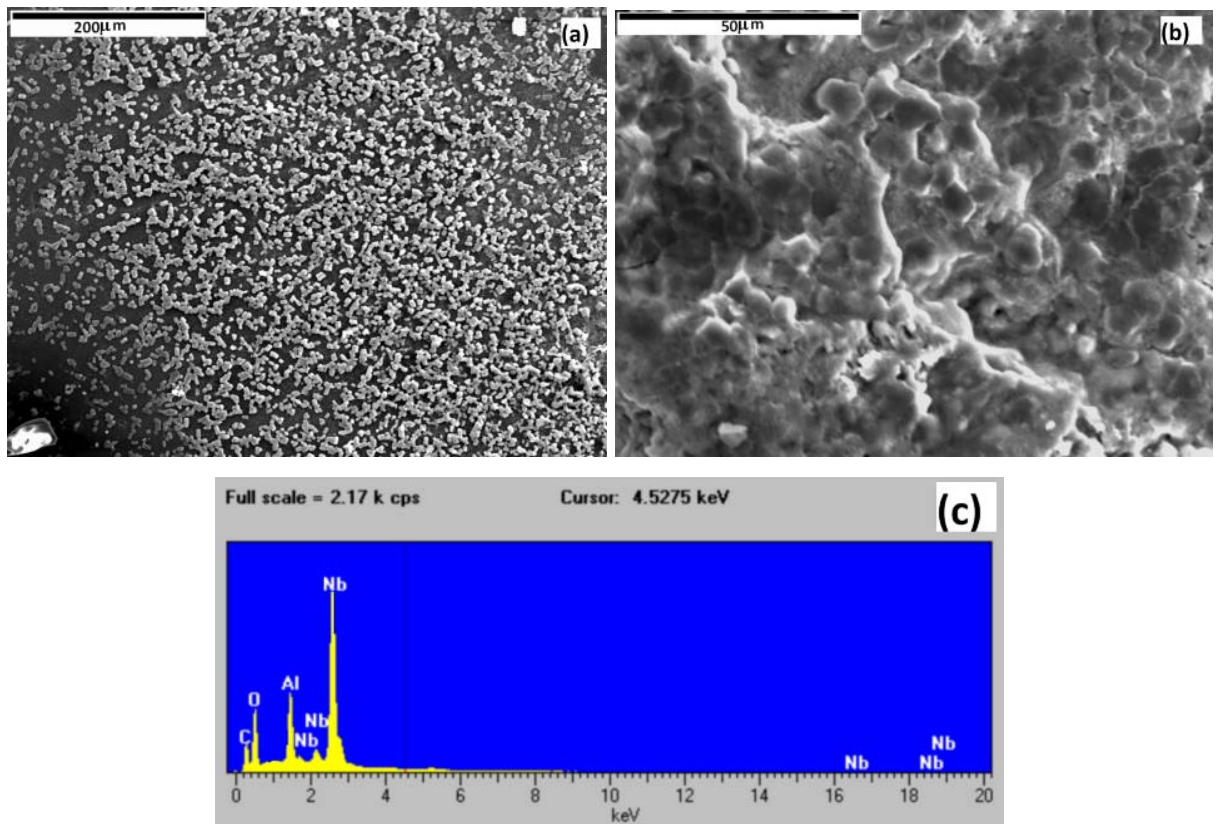

Fig. 3. SEM photograph of a vitreous carbon electrode surface recorded after 2 hours of potentiostatic pulse of $-0.450 \mathrm{~V} v$ s. Al cathodic overpotential applied in $\mathrm{AlCl}_{3}+\mathrm{NaCl}$ melt with added $\mathrm{Nb}_{2} \mathrm{O}_{5}, \mathrm{~T}=200^{\circ} \mathrm{C}$ : a) magnification 200x; b) magnification 1000x; ) EDS analysis of the sample given as a) and b).

Results of SEM and EDS analysis obtained from vitreous carbon electrode, in the electrolyte used with the niobium added by $\mathrm{Nb}_{2} \mathrm{O}_{5}$ dissolution, exposed for 2 hours to a potential step reaching into aluminium overpotential region are presented in Fig.3. The deposit shown in Fig.3. a) and b) was identified in Fig.3.c) as $\mathrm{Nb}$ and Al. These findings support the assumptions made earlier that niobium and aluminium have been deposited and codeposited. A trace of oxygen was impossible to avoid because the samples had to be exposed to the air during handling.

Typical examples of voltammograms recorded with vitreous carbon electrode in the electrolyte made of equimolar $\mathrm{AlCl}_{3}+\mathrm{NaCl}$ mixture with niobium added by anodic dissolution of $\mathrm{Nb}$ metal, are presented in Fig.4. a), b) and c). 

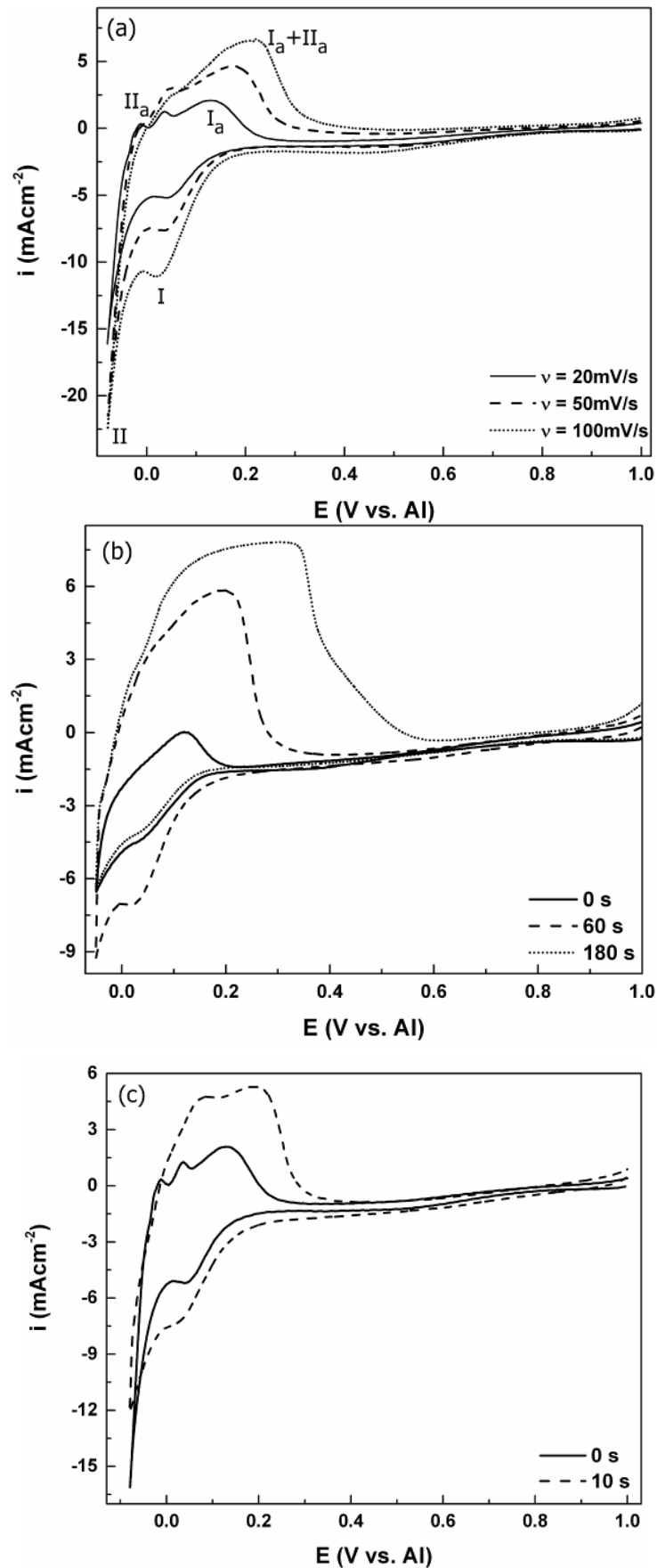

Fig. 4. Voltammograms recorded on vitreous carbon electrode in $\mathrm{AlCl}_{3}+\mathrm{NaCl}$ melt with $\mathrm{Nb}$ added by anodic dissolution of $\mathrm{Nb}$ : $\boldsymbol{a})$ different sweep rates applied; $\boldsymbol{b}$ ) and

c) cathodic end potential, $E_{f}$, being held for different time, $v=10 \mathrm{mV} / \mathrm{s} ; \mathrm{T}=200{ }^{\circ} \mathrm{C}$. 
Some differences between the voltammograms shown in Fig.2. a) and b) recorded in the melt with niobium added by $\mathrm{Nb}_{2} \mathrm{O}_{5}$ dissolution and these ones shown in Fig.4. a), b) and c) are obvious. First, the number of reduction and oxidation peaks is different and second, the starting potentials of the recorded peaks are different.

In Fig. 4 a), b) and c) there is one reduction peak and one reduction current increase: the first (situated at more positive potentials (I) starting at around $0.100 \mathrm{~V}$ vs. $\mathrm{Al}$ ) reflects niobium deposition, and the second (situated at more negative potentials (II) starting at around $-0.025 \mathrm{~V}$ vs. Al) reflects aluminium deposition and codeposition with $\mathrm{Nb}$. Analysis of the niobium deposition peaks obtained with different sweep rates (e.g. Fig. 4.a) according to relation $i_{\text {peak }}=v^{1 / 2}$ resulted in a straight line, suggesting diffusion controlled niobium deposition. This has been expected, because niobium concentration in the electrolyte was relatively small. The dissolution of the niobium electrodeposited (the first reduction peak $\mathrm{I}$ ) is reflected in the oxidation peak positioned at the most positive potentials $\left(\mathrm{I}_{\mathrm{a}}\right)$. However, dissolution of the aluminium deposited and codeposited with niobium is reflected partly by already mentioned oxidation peak $\left(\mathrm{I}_{\mathrm{a}}\right)$ and by the other two positioned at more negative potentials $\left(\mathrm{II}_{\mathrm{a}}\right.$ and $\mathrm{I}_{\mathrm{a}}+\mathrm{II}_{\mathrm{a}}$ ). At potentials from $0.700 \mathrm{~V}$ vs. Al to $0.300 \mathrm{~V}$ vs. Al, sometimes traces of a reduction peak (with no oxidation counterpart) can be noticed. This might be reflection of a very small concentration of $\mathrm{Nb}(\mathrm{V})$ ions, product of anodic niobium dissolution, being reduced to some lower oxidation state [12,13,21].
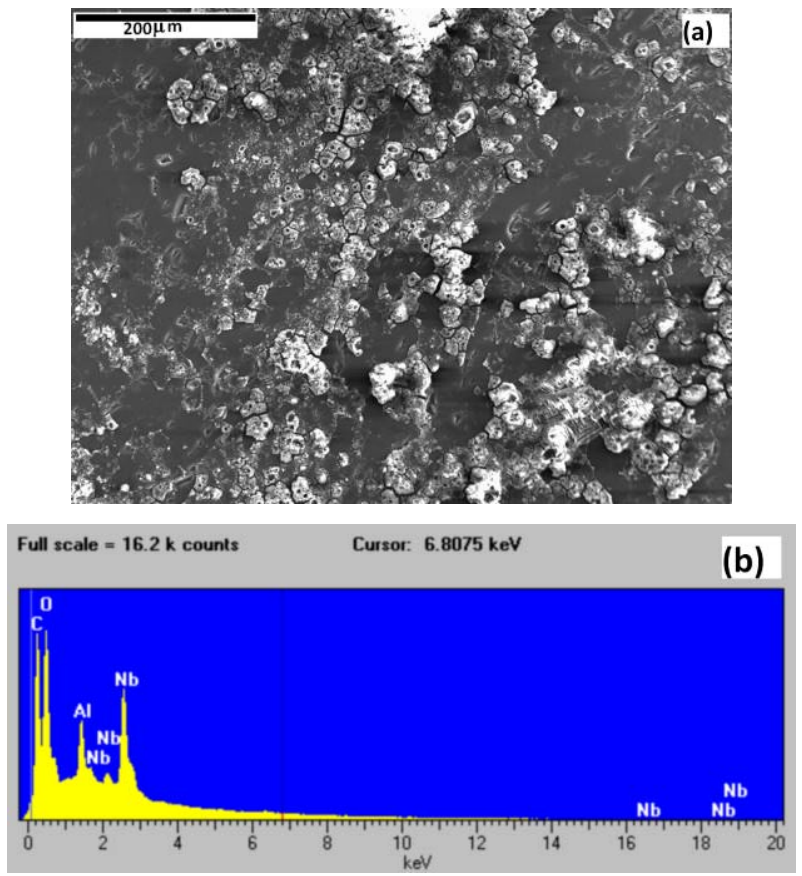

Fig. 5. a) SEM photograph of the vitreous carbon electrode surface recorded after 4 hours of $-0.030 \mathrm{~V}$ vs. Al cathodic overpotential applied as potentiostatic pulse in $\mathrm{AlCl}_{3}+\mathrm{NaCl}$ melt with $\mathrm{Nb}$ added by anodic dissolution, magnification $170 \mathrm{x}$;

b) EDS analysis of the sample given as a); $T=200^{\circ} \mathrm{C}$. 
The results obtained with cyclic voltammetry in the electrolyte with niobium added by anodic dissolution on working electrode held for some time at the cathodic end potential, $\mathrm{E}_{\mathrm{f}}$, entering both $\mathrm{Nb}$ and $\mathrm{Al}$ overpotential region, are shown in Fig. 4.b) and c) and support the general picture of niobium deposition and Al-Nb codeposition and alloy formation on vitreous carbon from used melt. Further confirmation was found in SEM and EDS analyses of the vitreous carbon surfaces being exposed for some time to potential step into aluminium overpotential region, Fig.5. a) and b). Clear evidence of $\mathrm{Nb}$ and $\mathrm{Al}$ being present in the grains of deposit from Fig.5.a) is shown in Fig.5.b).

\section{Conclusions}

Niobium was electrodeposited individually and codeposited with aluminium onto vitreous carbon from the melts made of $\mathrm{AlCl}_{3}+\mathrm{NaCl}$ equimolar mixture enriched with niobium at temperature $\mathrm{T}=200{ }^{\circ} \mathrm{C}$.

From the electrolyte made of equimolar $\mathrm{AlCl}_{3}+\mathrm{NaCl}$ mixture with $\mathrm{Nb}$ added by $\mathrm{Nb}_{2} \mathrm{O}_{5}$ niobium deposition starts at about $-0.100 \mathrm{~V}$ vs. Al and aluminium codeposition at around $-0.200 \mathrm{~V}$ vs. Al, while from the electrolyte with niobium added by anodic dissolution of niobium, deposition starts at about $0.100 \mathrm{~V}$ vs. Al and aluminium codeposition at around $-0.025 \mathrm{~V}$ vs. Al.

Codeposition of niobium and aluminium enables formation of $\mathrm{Nb}-\mathrm{Al}$ alloy in a very controlled way by applying appropriate potential of electrodeposition at temperatures much lower than the temperatures used in conventional metallurgy. At aluminium overpotentials higher than $-0.200 \mathrm{~V}$ vs. Al (in the melt with dissolved $\mathrm{Nb}_{2} \mathrm{O}_{5}$ ) and $-0.025 \mathrm{~V}$ vs. Al (in the melt with anodically dissolved $\mathrm{Nb}$ ), $\mathrm{Nb}$-Al alloys with comparable content of both components are formed. For a given time of deposition, presence of $\mathrm{Nb}$ in a deposited alloy is controlled by $\mathrm{Nb}$ concentration in the electrolyte used and $\mathrm{Al}$ content is decided by the aluminium overpotential (current density) applied.

\section{Reference}

[1] I. Nowak, M. Ziolek, Chem. Rev. 99 (1999) 3603-3624.

[2] B.A. Glowacki, X.-Y. Yan, D. Fray, G. Chen, M. Majoros, Y. Shi, Physica C Supercond. 372-376 (2002) 1315-1320.

[3] R. Olivares-Navarrete, J.J. Olaya, C. Ramirez, S.E. Rodil, Coatings 1 (2011) 72-87.

[4] G.R. Kamat, C.K. Gupta, Metall. Trans. 2 (1971) 2817-2823.

[5] C.R. Kachelmyer, A.S. Rogachev, A. Varma, J. Mater. Res. 10 (1995) 2260-2270.

[6] W. Loer, R. Hermann, M. Leonhardt, D. Dtephen, R. Bormann, Mater. Sci. Eng. A 224 (1997) 53-60.

[7] E. Botcharova, M. Heilmaier, J. Freudenberger, D. Kudashow, U. Martin, L. Schultz, J. All. Compd. 351 (2003) 119-125.

[8] S. Senderoff, G.W. Mellors, J. Electrochem. Soc. 113 (1966) 66-71.

[9] K.D. Sienerth, E.M. Hondrogiannis, G. Mamantov, J. Electrochem. Soc. 141 (1994) 1762-1769.

[10] S.A. Kuznetsov, Russ. J. Electrochem. 36 (2000) 509-515.

[11] C.L. Hussey, Final Report, AFOSR Grant F49620-00-1-0123, (2000-2004) 1-162.

[12] V. Van, A. Silny, J. Hives, V. Danek, Electrochem. Commun. 1 (1999) 295-300.

[13] E. Christensen, X. Wang, J.H. von Barner, T. Ostfold, N.J. Bjerrum, J. Electrochem. Soc. 141 (1994) 1212-1220. 
[14] J.H. von Barner, N.J. Bjerrum, Inorg. Chem. 44 (2005) 9847-9851.

[15] B. Kubikova, V. Danek, M. Gauene-Escard, Z. Naturforsch. 62a (2007) 540-544.

[16] V. Špetuch, J. Petrik, E. Grambalova, Metall. Mater. Eng., 19 (2013) 23-31.

[17] I.A. Wixtrom, E.J. Buhler, E.C. Reece, M.T. Abdel-Fattah, ECS Transaction 50 (2012) 225-228.

[18] J. Fischer, M. Mann, B. Prout, K. Leadbetter, M. Kadink, D. Siks, UND Engineering AEM Center, Annual Report, No. 130410 JKF, (2013).

[19] E.I. Dyachkov, R. Herzog, I.S. Khukhareva, A. Nichitiu, Cryogenics, 21 (1981) 4750.

[20] S. Franz, E. Barzi, D. Turrioni, L. Glionna, M. Bestetti, Mater. Lett. 161 (2015) 613-615.

[21] L.P. Polyakova, P. Taxil, E.G. Polyakov, J. All. Compd. 359 (2003) 244-255.

[22] M. Mohamedi, N. Kawaguchi, Y. Sato, T. Yamamura, J. Alloys Compd., 287 (1999) 91-97.

[23] G.R. Stafford, G.M. Haarberg, Plasmas \& Ions 1 (1999) 35-44.

[24] F. Lantelme, A.Salmi, B. Coffin, J.Claverie, Y. Le Petitcorps, Mater. Sci. Eng. B, 39 (1996) 202-207.

[25] Y. Sato, K. Iwabuchi, N. Kawaguchi, H. Zhu, M. Endo, T. Yamamura, S. Saito, In: Tenth International Symposium on Molten Salts, PV 96-7, The Electrochemical Society,Inc. Pennington, 1996, p. 179.

[26] K. Koura, T. Kato, E. Yumoto, J. Surface Finish. Soc. Jpn. 45 (1994) 805-809.

[27] N. Jovićević, V. S. Cvetković, Ž. J. Kamberović, J. N. Jovićević, Metall. Mater. Trans. B, 44 (2013) 106-114.

[28] R.S. Nicholson, I. Shain, J. Anal. Chem., 36 (1964) 706-723. 